\title{
Covid-19 Disaster Mitigation Policy in Surabaya in Pressing Positive Increasing Numbers
}

\author{
Sri Mastuti* \\ History Education Department \\ Faculty of Social Sciences and Law, \\ Universitas Negeri Surabaya, Indonesia \\ srimastuti@unesa.ac.id
}

\author{
Thomas Nugroho Aji \\ History Education Department \\ Faculty of Social Sciences and Law, \\ Universitas Negeri Surabaya, Indonesia \\ thomasnugroho@unesa.ac.id \\ Corry Liana \\ History Education Department \\ Faculty of Social Sciences and Law, \\ Universitas Negeri Surabaya, Indonesia \\ corryliana@unesa.ac.id
}

\author{
Nasution \\ History Education Department \\ Faculty of Social Sciences and Law, \\ Universitas Negeri Surabaya, Indonesia \\ nasution@unesa.ac.id
}

\begin{abstract}
The Corona virus was first discovered in the Wuhan-China region (Hui DS, 2020), and has become such a big problem that it has disrupted aspects of the social life of people throughout the world, including Indonesia. This is hampering the process of all fields such as economics, education, and public services. The presence of COVID-19 presented panic in the world community. The City Government of Surabaya, under the coordination of the Provincial Government of East Java, has imposed a Large-Scale Social Restriction (PSBB) to prevent massive transmission of the population. The research method chosen in this study is a descriptive qualitative method. As part of the qualitative method, a qualitative descriptive approach includes the construction of social reality and cultural meaning, focusing on interactive processes, events, authenticity, not free of values, integrated theory, and situational or contextual data and theories, and researcher involvement.
\end{abstract}

Keywords: Covid-19, Mitigation Policy, Surabaya, LargeScale Social Restriction (PSBB), Pandemic

\section{INTRODUCTION}

The COVID-19 pandemic became a world disaster in the form of the first and foremost health crisis in the world. Many countries decide to make policies to close their countries. The Italian government closes the northern part of the country, leaving 15 million people at risk of being unable to travel. According to reports, the US Centers for Disease Control and Prevention (CDC) in Italy reported 189,973 cases, with 25,549 people dead. In France, there are 158,183 COVID-19 cases and have killed 21,856 people. Spain and Germany also reported hundreds of cases of Covid-19 in their respective countries which reached 213,024 and 153,129. Indonesia's strategic trading partner countries such as China, South Korea, Japan and Italy have now become the countries with the most cases of corona virus infection in the world. To prevent the ever expanding COVID-19, each country issued a social distancing policy that has now turned into physical distancing according to WHO's call. WHO has also recommended several countries affected by the spread of the covid-19 pandemic to conduct Lockdown policies in countries affected by the virus.

The number of positive cases of corona virus (Covid19) in Indonesia has exceeded ten thousand patients. After a significant decline, the number of new positive cases confirmed in the last few days has increased dramatically. Based on data from the Task Force for the Acceleration of Covid-19 Handling, the total number of positive corona cases in Indonesia is now over 10,000 patients. Of these, as many as 8000 more Covid-19 patients are still in care. Whereas more than 1000 other positive corona patients have been declared cured. The number of positive cases is increasingly rising, requiring special treatment that can be done to overcome the surge in positive cases of COVID-19. Every country, province and region are expected to have policies in overcoming this pandemic

The dynamics of COVID-19 positive cases also occur in the city of Surabaya, the Corona COVID-19 case still shows an increase in Surabaya, East Java until April 24, 2020. The increase is both the number of positive patients and recovered from Corona COVID-19 (lawancovid19.surabaya. com, 2020). Based on Surabaya City Health Department sources, the total number of people under monitoring (ODP) increased by 71 people to 2,196 people until April 24, 2020. In the period of April 23, 2020, the total ODP was 2,125 people. Of the total ODP, 1,239 people have completed ODP monitoring and 957 people have been monitored. The number of patients under surveillance (PDP) increased to 935 people until April 24, 2020. Of the total PDP, PDP under supervision of 590 people, PDP recovered to 343 people and PDP died two people. The research method chosen in this study is a descriptive qualitative method. As part of the qualitative method, a qualitative descriptive approach includes the construction of social reality and cultural meaning, focusing on interactive processes, events, authenticity, not free of values, integrated theory, and situational or contextual data and theories, and researcher involvement 
Based on the description above, the researcher is interested in conducting research that examines local government policies in handling the COVID-19 pandemic, especially in the Surabaya area.

\section{METHOD}

The research method chosen in this study is a descriptive qualitative method. As part of the qualitative method, a qualitative descriptive approach includes the construction of social reality and cultural meaning, focusing on interactive processes, events, authenticity, not free of values, integrated theory, and situational or contextual data and theories, and researcher involvement (Creswell, 1994). Qualitative methods according to Creswell (2013) have the characteristics of a natural setting, researchers as a key instrument, multiple sources of data, inductive data analysis, participants'amaning, emergent design, theoretical lens, interpretative, and holistic account.

This research builds patterns, categories, and themes from the bottom up (inductive), by processing data spread of COVID-19 into more abstract information units. In the ontological, epistemological, axiological, rhetorical, and methodological dimensions, research with qualitative methods has paradigmatic assumptions as suggested by Creswell (1994).

This research is exploring to find answers to research questions on how government policies in handling the spread of COVID-19 in Surabaya. For the purposes of finding answers to these questions, the type of qualitative research chosen in this study is case study research. As stated by Emzir (2011), this type of research was chosen because the researcher tried to find meaning, investigate the process, and obtain in-depth understanding and understanding from individuals, groups, or situations. This choice is also in accordance with Yin (2004) 's suggestion that case studies have specific characteristics which are: a) investigating contemporary phenomena in real life contexts, 2) boundaries between phenomena and contexts are not clear, and 3) using multiple sources of evidence.

\section{RESULTS AND DISCUSSION}

Covid-19 virus began to enter Indonesia in mid-March and had become a popular topic in recent weeks. The World Health Organization (WHO) finally established this event as a pandemic after 114 countries were recorded as having some infected case of this virus.

This makes Indonesia must take fast steps to reduce the spread of the covid-19 virus. The step taken by the government at this time is to conduct social distancing to the community where this policy is expected to minimize the spread of this virus. There are so many opinions that the social distancing is not very effective in overcoming current problems. Some of people demanded the government to lockdown policy in Indonesia, but President Joko Widodo (Jokowi) refused to make that policy.

This policy is considered to have an effect on the Indonesian economy. Many Indonesians earn a daily income so that if they apply a lockdown policy, they will lose income so that it will cause other problems. Not only about viruses can even be an economic crisis or make many Indonesian people starve and create other problems in the middle of the current virus problem. President Joko Widodo has issued a number of decisions to address the co19 pandemic in Indonesia. With points that are the focus of the government to deal with the health, social and economic conditions of Indonesia are listed in Government Law (PeraturanPemerintah) Number 1 of 2020, Presidential Decree Number 11 of 2020, and Government Law Number 21 of 2020.

East Java Governor Signs the Governor Regulation Number 18 of 2020 concerning Guidelines for Large-Scale Social Restrictions (Pembatasan Sosial Berskala Besar) in Handling Covid-19 in East Java. Specially in Sidoarjo Regency. East Java Governor Regulation No. 18 of 2020 contains nine chapters of the main rules and 33 articles. In general, the governing regulation contained several things that are restricted during the implementation of the CBDR in the Greater Surabaya area. Such as operational restrictions on educational institutions and teaching and learning activities in schools, other educational institutions, and fieldwork practices.

\subsection{Surabaya Government's Policy in Overcoming COVID-19}

Surabaya City Government made a circular containing protocols to deal with the spread of the corona virus (COVID-19) in a number of places in Surabaya. Some places that have protocols include, government environment, health environment, airports and other places of entry and exit, education environment, public transportation, markets and trade areas, shopping centers and convenience stores, hotels, restaurants, recreation areas, religious environments, offices and industrial areas, and other public places. In a circular numbered 360/3324 / 436.8.4 / 2020, the Mayor of Surabaya calls for:

1. All citizens to increase their vigilance by staying clean and healthy, and avoiding crowds and travel.

2. All schools under the authority of the Surabaya City Government to implement online learning.

3. All public services of the Surabaya City government continue to operate using online / online media and for public-managed public services are advised to adjust to the policies of the Surabaya City Government.

4. All agencies, including the private sector, must implement maximum health standards and take part in efforts to prevent the spread of COVID-19 according to the protocol established by the government.

5. All health workers and facilities are on standby to face the COVID-19 pandemic in Surabaya.

6. Residents who see and feel the symptoms of COVID19 in their neighborhood, can immediately contact Command Center 112 or directly to the nearest Society Health Center (Puskesmas) / hospital or the clinic.

Previously the Surabaya government had taken various strategic steps in preventing COVID-19 from spreading in the city of Surabaya, these steps included:

1. Distribute ginger drinks and boiled eggs. Surabaya City Government established a public kitchen and complaints post in Taman Surya, Surabaya City Hall. The public kitchen provides herbal drinks (pokak drink) made from ginger and spices. The public kitchen not only prepare the herbal drink but also prepare boiled eggs for 1,000 people. Drinks and snacks are believed 
can increase endurance and body immune. The ginger drinks and boiled eggs are distributed to all residents.

2. Use loudspeakers, socialize on the streets. The Mayor of Surabaya descends immediately to provide socialization on the city streets. By using a car and loudspeaker, the mayor went around the city while delivering a message that residents who congregate in public spaces keep a minimum distance of 1 meter for breaking the chain of COVID-19 distribution.

3. Sterilization of 1,262 Schools. While students study at home the Surabaya City Government sterilizes 1,262 elementary and junior high schools. In addition, schools with many students will also be added by installing portable sinks so that the school environment is completely sterile. Besides that, disinfectant spraying is also done to sterilize schools.

4. Public Services Use Online Media. All public services of the Surabaya City Government continue to operate by using online / online media and for public-managed public services are advised to adjust to the Surabaya City Government's policies. All Surabaya City Government activities involving the masses such as religious activities, concerts, and Integrated Healthcare (Posyandu) were temporarily stopped. all markets, shops, shopping centers and modern stores to implement maximum health standards and prevent the spread of Covid-19 in accordance with the Market Protocol and Trade Zone.

5. Message of the COVID-19 Sterilization Chamber and Disinfectant Spraying. City Government of Surabaya in collaboration with Telkom Surabaya Institute of Technology (IT) developed a sterilization chamber. a gar can suppress the rate of corona virus spread in the city of Surabaya. spraying disinfectant into residential areas, making disinfectant booths and placing them in offices, public facilities and other public places. The municipal government has also expanded the installation of sinks in various places, and also spreads hand sanitizers.

6. Provision of PPE (Personal Protective Equipment). Surabaya City Government gave PPE (personal protective equipment) to the hospital in Surabaya that had been appointed as a reference for handling Covid19. Not only hospitals owned by the municipal government, but all referral hospitals in Surabaya.

7. Provision of groceries. Surabaya City Government also provides additional food, by providing food to the MBR (low-income people).

8. Provision of COVID-19 Information. All information related to Covid-19 can be seen on page: https://linterovid-19.surabaya.go.id. This official website provides various information about Covid-19 and services prepared by the Surabaya City Government in handling and preventing transmission of this virus. The website also prepares a consultation room, actions to map the distribution of Covid-19 patients in the city of Surabaya. (lawancovid19.surabaya.go.id,)

\subsection{Implementation of Large-Scale Social Restrictions Policy (PSBB) in Surabaya as a Form of COVID-19 Disaster Management}

Referring to Minister of Health Regulation No. 9 of 2020 concerning Large-Scale Social Limitation Guidelines (PSBB), Minister of Health Decree Number HK.01.07 / MENKES / 264/2020 concerning Determination of LargeScale Social Restrictions in Surabaya City, Sidoarjo Regency, and Gresik Regency, East Java Province. As well as the Surabaya Mayor Regulation No.16 in 2020, Surabaya is a city that is registered in the area that applies the PSBB in East Java. Of the 31 districts in the city of Surabaya, all sub-districts already have positive cases of COVID-19. PSBB is implemented for 14 (fourteen) days, starting from April 28, 2020 until May 11, 2020. In the event that there is still evidence of the spread of COVID-19 at the end of PSBB, the PSBB can be extended (Decree of East Java Governor No.18 / 202 / KPTS / 013/2020)

1. Establishment of Surabaya Large Scale Social Restrictions (PSBB) Provisions. Based on Surabaya Mayor Regulation number 16 of 2020, there are a number of points that are restricted and allowed in PSBB in Surabaya City, while the provisions are presented in the following figure:

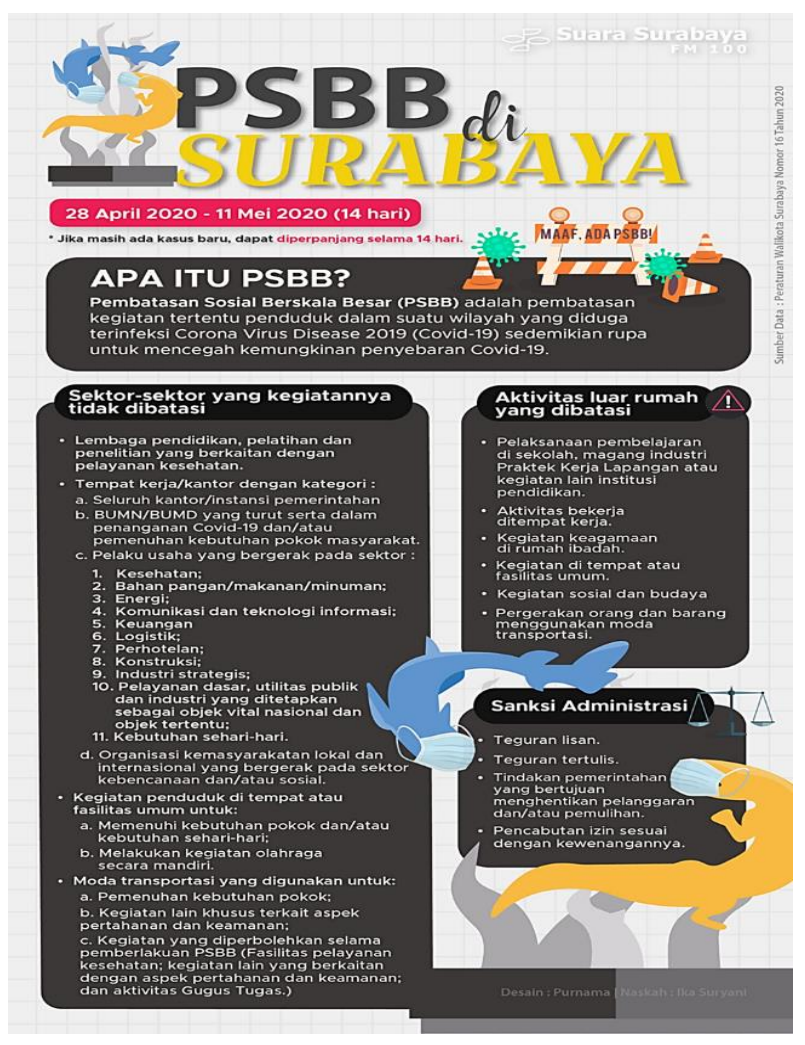

2. Cooperation with Various Parties and Stakeholders in the Implementation of Surabaya PSBB. One of the educational institutions that collaborate with Surabaya City Government is Airlangga University. Airlangga University Hospital (RSUA) provides a free corona virus examination service. It is a form of cooperation between the City Government of Surabaya and RSUA. For the people of Surabaya, if they experience symptoms of heat, cough, runny nose, headache, 
shortness of breath it can be directly examined at RSUA. Costs borne by Surabaya City Government include free ambulance to pick up.

In addition to the education institution, the municipal government also cooperates with several companies in the procurement of PPE for medical personnel who handle Covid-19. Sinar Mas Land, to protect the medical staff at the referral hospital in the Surabaya City area in handling Covid-19 patients. Sinar Mas Land handed over 1,000 personal protective equipment (PPE) to the Covid-19 referral hospital in Surabaya.

The City Government also cooperates with several hotels to provide rooms. The City Government has provided hundreds of hotel rooms as a place of isolation for the families of COVID-19 patients. Currently the City Government is preparing 265 hotel rooms for those who are negative. In a sense those whose families are positive and are separated from the family and moved to the hotel

\subsection{PSBB Policy Results and Evaluations in Surabaya}

The first day of the implementation of large-scale social restrictions (PSBB) in Surabaya city, Gresik city, and Sidoarjo city on 28 April 2020 was immediately evaluated. One result is that the East Java Provincial Government has asked employers to regulate employee work hours. That way, the congestion that appeared yesterday at some checkpoints does not repeat itself

There was a severe traffic jam at the Waru sub-district roundabout which became the Surabaya-Sidoarjo border area. Congestion occurs from 6:10 to 09:00. Vehicle buildup occurs in two directions, namely Sidoarjo and Waru sub-district roundabout exit tolls. The large number of road users overwhelms officers to carry out checks. From 19 point border posts in Surabaya, Waru roundabout is the focus of officers. Because, there are many vehicles that want to enter Surabaya. Especially when leaving for work.

While at the monitoring post at RungkutMenanggal sub-district, there are still many public vehicles full of passengers, not half filled according to the rules set. At the Suramadu bridge border post, vehicles from Madura island that do not obedient the rules are required to turn around. The condition was slightly deserted at the Osowilangun sub-district border post, vehicles passing downhill than usual but strict checks were still carried out. Other violations were seen in restaurants, restaurants and coffee shops. There are still many who serve food and drink buyers on the spot. In fact, according to the rules, all eating and drinking places are only allowed to take away or take home.

\subsubsection{The Covid-19 Case Increases in the First and Second Week of the PSBB}

The implementation of Large Scale Social Restrictions (PSBB) in Greater Surabaya, which includes Surabaya, Sidoarjo and Gresik, have yet to show results. Based on the East Java Covid-19 Task Force Handling Curative Cluster Team, the positive cases of Covid-19 in Surabaya have increased in the last few days. On the third day of the PSBB, 44 positive cases were found. Then there were 58 positive cases on the fourth day of the implementation of the PSBB. Then, on the sixth day there were 59 cases. However, on the 11th day of the application of the PSBB, there were no additional positive cases of Covid-19 in the city of Surabaya. In addition, the number of PDP in Surabaya also increased. On the second day of the application of the PSBB there were 66 PDP additions. Then, on the fourth day there were 33 PDP. Furthermore, on the eighth day of the PSBB there were 67 PDPs and on the tenth day there were 107 PDPs.

Based on studies from epidemiologists about the spread of Covid-19, as many as 70 percent of people are infected and the infection process can keep moving for more than 14 days. 14 days of PSBB which had been carried out in Greater Surabaya after being examined epidemiologically were considered insufficient to guarantee the cessation of the spread of Covid-19.Per on May 10, 2020 confirmed positive of Covid-19 in the treatment of 518 cases. Covid-19 positive confirmed recovery, a total of 101 cases. The Covid-positive case confirmed recovering outside Surabaya, a total of 5 cases. The cumulative positive confirmed Covid-19 numbered 708. Thus the cumulative positive confirmed Covid-19 Surabaya 700 cases and the cumulative positive confirmed Covid-19 outside Surabaya as many as 8 cases. The surge in patients positively infected with corona (Covid-19) in Surabaya was a result of not being accompanied by an increase in community adherence to health protocols.

\subsubsection{Large Clusters}

The City Government of Surabaya, East Java continues to do tracing to find confirmed citizens of Covid19 or corona virus. To date, 16 clusters have been found in the spread of the corona virus in Surabaya. The 16 clusters included the first overseas clusters, the second nine public areas, the three Jakarta clusters, and three workplaces. Then, there are two seminar and training clusters, and two offices and dormitories.

According to the Mayor of Surabaya, if a search was found to be confirmed, then that person became part of an overseas cluster. As Sampoerna's cluster, it is not a new cluster. Of the 16 clusters, the most recent number of patients as of May 9, 2020 for people in monitoring (ODP) was 2,957, consisting of 153 inpatients and 587 outpatients. Then that has been monitored as many as 2,217. Patients under surveillance (PDP) numbered 1,540 from there divided outpatient 273 and inpatient 663. 601 have been monitored and died 3 people. For patients confirmed by Covid-19 the number reached 667 patients. Of that number, 343 people are being hospitalized and 144 outpatients. Then for 100 patients recovered. While those who died numbered 80 people.

\subsubsection{Over Capacity}

The city of Surabaya has provided around 120 beds to support the additional capacity of Covid-19 patient ward in private hospitals. In addition, the City of Surabaya government increased the number of patient care rooms in regional public hospitals. Especially for "dr. M Soewandhie" local city hospital, the city government supports the addition of 36 patient rooms so that a total of 58 rooms are available. While the Bhakti Dharma Husada, the Regional Hospital prepare 12 rooms will be added 52 rooms so that there will be a total of 64 rooms. The 
Surabaya City Government also prepared 265 hotel rooms for isolation rooms after Covid-19 patient care rooms in all referral hospitals were filled to exceed capacity.

\subsection{Surabaya PSBB Extension Policy}

East Java Covid-19 Task Force assesses that the indicators of the success of the Large Scale Social Restrictions (PSBB) listed in Minister of Health regulation (Permenkes) number 9/2020 on the PSBB Guidelines have not been reached in the first phase of the PSBB in Surabaya, Sidoarjo, and Gresik. happen. The decline in the death rate of Covid-19 cases in three regions, as well as the absence of spreading to new areas or the cessation of local transmission have not yet occurred.

There are many evaluations that must be done by Surabaya City Government with the first phase of the PSBB already underway. For example, what are the measurable targets for implementing CBDRR. Targets include the number of sample tests and PCR tests that have been carried out. In addition, it also needs to be measured to what extent the aggressiveness of tracking the spread of Covid-19 has been carried out. It also needs to be examined, how closely monitoring the potential of Covid-19 distribution in several clusters

Extension of PSBB period for 14 days or starting May 12, 2020 until May 25, 2020. The decision was an agreement taken by the Governor together with Regional Leadership Coordination Forum (Forkopimda) from all region in East Java and three regional heads representing the City of Surabaya, Sidoarjo Regency and Gresik Regency. The decision to extend the PSBB period was also taken after see the results of epidemiological studies that show the pattern of the spread of Covid-19 is still high, especially for the city of Surabaya. Based on studies conducted, that some of the infected patients have a transmission period of more than 14 days. Only 30 percent of positive people are Covid-19 whose transmission period only 14 days, then another 35 percent can transmit up to 21 days. And as many as 15 percent of people who are infected with the transmission reach 28 days to 30 days,

Another fact that is the reason for the extension of the Large Scale Social Restrictions is that all indicators of success have not been achieved as stated in the Minister of Health Regulation 9/2020 on PSBB Guidelines. Among these are the reduction in the number of Covid-19 confirmation cases, reduction in mortality and no spread to new areas or occurrence local transmission. Meanwhile, based on the results of the evaluation conducted by the Curative Cluster Task Force for the East Java Covid-19 Handling Acceleration, the implementation of Gresik and Sidoarjo Large Scale Social Restrictions was considered relatively successful due to the decreasing trend of transmission of transmission, Surabaya City still needs more hard work because it still has. Continuing to increase the number of patients confirmed positive Covid-19.

16 contagion clusters in Surabaya include public area clusters, workplaces, offices, houses of worship, seminars, dormitories, and travelers from out of town and abroad. Two of the most infectious clusters are residents, namely the public area cluster, PPI Market on Gresik street, and "the Sampoerna" cigarette factory workplace cluster, with more than 30 people.
The addition of positive confirmed cases during the PSBB was due to massive testing. The City Government has conducted contact tracing and conducted rapid tests and PCR tests on people under monitoring (ODP), patients under surveillance (PDP), and people without symptoms (OTG). In March-April 2020, the City Government of Surabaya was only able to conduct PCR tests on 230 persons. The number of inspections more than tripled in early May 2020, reaching 853 people. The number of positive patients is estimated to continue to grow because until now there are still around 800 patients waiting for PCR results.

Surabaya Mayor, Tri Rismaharini stated, the surge in cases that occurred during the last two weeks was the result of many tests. Additional positive patient confirmation, according to him, is better than undetected so that it has the potential to transmit it to others.

Entering the second period of PSBB, which will take place May 12-25, the mayor has asked residents to comply more with the established health protocol. If there is no urgent need, residents are asked to remain at home in order to reduce meetings with others who have the potential to transmit the SARS-CoV-2 virus that causes Covid-19. If you still have to work, to keep a minimum distance of 2 meters between employees.

\section{CONCLUSIONS AND SUGGESTIONS}

\section{A. Conclusion}

The Surabaya city government in the face of the covid19 pandemic virus has mitigated to find confirmed citizens of Covid-19 or corona virus, preparing 265 hotel rooms for isolation rooms after Covid-19 patient care rooms in all referral hospitals were filled beyond capacity. The enactment of the PSBB was stipulated by the Governor of East Java in the governor law due to the positive cases of COVID-19 continuing to increase in the Surabaya area. The extension of the PSBB period for 14 days or starting May 12, 2020 to May 25, 2020. The decision to extend the PSBB period was also taken after seeing the results of epidemiological studies that showed the pattern of the spread of Covid-19 was still high, especially for Surabaya City.

\section{B. Suggestions}

This research requires more approaches such healthy, economic and culture aspects. Healthy aspect is more important along with social approach (anthropology and history) to make a better understanding the cultural and history aspects of public health in Surabaya.

\section{REFERENCES}

[1] Abdul Wahab, Solichin. 2008. Analisis Kebijaksanaan dari Formulasi ke Implementasi Kebijaksanaan Negara. Jakarta : Bumi Aksara.

[2] Anderson, James E. 1969. Public Policy Making. New York: Holt, Rinehart and Winston, 2nded.

[3] W. "Novel coronavirus to be called COVID-19, 11 ruari 2020. [Online]. 
[4] BBC, "Coronavirus disease named Covid-19," 11 Februari 2020. [Online]. Available: via www.bbc.co.uk.

[5] A. E. Gorbalenya, ""Severe acute respiratory syndrome-related coronavirus - The species and its viruses, a statement of the Coronavirus Study Group".," bioRxiv, 2020.

[6] N. Chen, M. Zhou, X. Dong, J. Qu, F. Gong, Y. Han, Y. Qiu, J. Wang, Y. Liu, Y. Wei and J. Xia, ""Epidemiological and clinical characteristics of 99 cases of 2019 novel coronavirus pneumonia in Wuhan, China: a descriptive study"," Lancet, vol. 395, p. 507513, 2020.

[7] I. A. E. M. T. N. F. K. R. D. O. I. G. M. T. M. Z. D. C. Z. A. P. E. Hui DS, "The continuing 2019-nCoV epidemic threat of novel coronaviruses to global health - The latest 2019 novel coronavirus outbreak in Wuhan, China.," Int J Infect Dis, vol. 14;91, p. 264-266, 2020.

[8] C. Pusat Pengendalian dan Pencegahan Penyakit, "2019 Novel Coronavirus (2019-nCoV)," 14 Februari 2020. [Online]. Available: https://www.cdc.gov/coronavirus/2019ncov/about/steps-when-sick.html.

[9] Worldometer, 24 April 2020. [Online]. Available: https://www.worldometers.info/coronavirus/.

[10] Tirto.id, ""Update Corona 24 April 2020 Indonesia \& Dunia: Perkembangan Terkini"," 24 April 2020. [Online]. Available: https://tirto.id/eVjw.
[11] W. N. Dunn, Pengantar Analisa Kebijakan Publik, Yogyakarta: Gadjah Mada Press, 2000.

[12] D. Indiahono, Kebijakan Publik Berbasis Dynamic Policy Analysis, Yogyakarta: Gava Media, 2009.

[13] C. O. Jones, Pengantar Kebijakan Publik (Public Policy). Terjemahan Ricky Ismanto, Jakarta: RajaGrafmdo Persada, 1996.

[14] E. Suharto, Analisis Kebijakan Publik, Bandung: Alfabeta, 2012.

[15] B. M. Faturahman, "Pemetaan Potensi Wilayah untuk Menunjang Kebijakan Pangan Kabupaten Pacitan," JISPO, vol. 7(2), p. 43-62, 2017.

[16] Halodoc.com, "halodoc," 25 April 2020. [Online].

Available: https://www.halodoc.com/kesehatan /coronavirus.

[17] lawancovid-19. surabaya.go.id, "Surabaya Lawan COVID-19," [Online]. Available: https:// lawancovid-19.surabaya. go.id/ berita-pemkot/baca/melalui-telencoferencewali-kota-risma-paparkan-kebijakanpenanganan-covid-19-ke-dprd-surabaya. 